\title{
Evaluation of the concentration of malondialdehyde and nitrite in patients with sickle cell anemia treated or not with hydroxyurea
}

\author{
Avaliação das concentrações de malonaldeído e nitrito em pacientes com anemia falciforme \\ em tratamento ou não com hidroxiureia
}

\author{
Darcielle Bruna Dias Elias ${ }^{1}$, Rivelilson Mendes de Freitas ${ }^{2}$, Romélia Pinheiro Gonçalves ${ }^{3}$, \\ Hemerson Yuri Ferreira Magalhães ${ }^{4}$, Jacqueline Holanda de Sousa ${ }^{5}$, Silvia Maria Meira Magalhães ${ }^{6}$
}

\begin{abstract}
Objective: To determine the serum levels of malondialdehyde and nitrite in patients with sickle cell anemia treated or not with hydroxyurea in outpatient's setting. Methods: Of the 65 patients with sickle cell anemia selected for the study, 51 were not treated with hydroxyurea (Group 1), 14 made chronic use of hydroxyurea (Group 2) and 20 individuals had no hemoglobinopathies (Control Group). Results: The Control Group had a lower and more homogeneous concentration of malondialdehyde levels as compared to the other groups. The results of Groups 1 and 2 showed increased values of malondialdehyde levels when compared to the Control Group. Considering the values of Groups 1 and 2, there were no significant changes in the malondialdehyde levels. There was no significant difference in the serum levels of nitrite between the groups. Group 2 presented a statistically significant correlation between serum malondialdehyde levels and the clinical variables investigated. In turn, Group 1 showed correlation only with occurrence of three or more vaso-occlusive crises. There was no correlation between nitrite levels and the clinical variables. Conclusion: The results revealed that during the pathogenesis of sickle cell anemia, an increase in lipid peroxidation was observed. On the other hand, no changes in oxidative parameters were detected during treatment with hydroxyurea, probably due to the short period of treatment of the patients studied.
\end{abstract}

Keywords: Anemia, sickle cell/drug therapy; Malondialdehyde; Thiobarbituric acid reactive substances; Nitrite; Oxidative stress; Hydroxyurea/therapeutic use

\section{RESUMO}

Objetivo: Determinar os níveis séricos de malonaldeído e de nitrito em pacientes com anemia falciforme em tratamento ou não com hidroxiureia e em acompanhamento ambulatorial. Métodos: Dos 65 pacientes com diagnóstico de anemia falciforme selecionados para o estudo, 51 não fizeram tratamento com hidroxiureia (Grupo 1) e 14 fizeram uso crônico de hidroxiureia (Grupo 2), sendo que 20 indivíduos não tinham hemoglobinopatias (Grupo Controle). Resultados: 0 Grupo Controle possuía menor e mais homogênea concentração dos níveis de malonaldeído em relação aos outros grupos. Os resultados do Grupo 1 e do Grupo 2 mostraram valores aumentados dos níveis de malonaldeído quando comparados ao Grupo Controle. Quando comparados os valores dos Grupos 1 e 2, não foram observadas alterações significativas nos níveis de malonaldeído. Não houve diferença significativa nos níveis séricos de nitrito entre os grupos. Verificou-se que, no Grupo 2, houve uma correlação estatisticamente significativa dos níveis séricos de malonaldeído com as variáveis clínicas investigadas. Por sua vez, o Grupo 1 mostrou correlação somente com a ocorrência de três ou mais crises vaso-oclusivas. Não se verificou nenhuma correlação nos níveis de nitrito com as variáveis clínicas. Conclusão: Os resultados revelaram que, durante o estabelecimento da patogênese da anemia falciforme, pode ser observado um aumento na peroxidação lipídica. Por outro lado, durante o tratamento com a hidroxureia, não foi detectada nenhuma alteração nos parâmetros oxidativos, provavelmente devido ao curto período de tratamento dos pacientes em estudo.

Descritores: Anemia falciforme/quimioterapia; Malonaldeído; Substâncias reativas com ácido tiobarbitúrico; Nitrito; Estresse oxidativo; Hidroxiureia/uso terapêutico

\footnotetext{
Study carried out at Hospital Universitário Walter Cantídio - HUWC, Fortaleza (CE), Brasil.

1 Pharmacist; PhD Student in Development and Technology Innovation of Drugs at Universidade Federal do Ceará - UFC, Fortaleza (CE), Brazil.

${ }^{2}$ Adjunct Professor at Univerisade Federal do Piauí - UFPI, Teresina (PI), Brazil.

${ }^{3}$ Associate Professor of Clinical Analyses and Toxicology Department at Universidade Federal do Ceára - UFC, Fortaleza (CE), Brazil.

${ }^{4}$ Professor of College of Pharmacy at Universidade Federal do Ceará - UFC, Fortaleza (CE), Brazil.

${ }^{5}$ Physician at Hospital Universitário Walter Cantídeo of Universidade Federal do Ceará - UFC, Fortaleza (CE), Brazil.

${ }^{6}$ Adjunct Professor at Universidade Federal do Ceará - UFC, Fortaleza (CE), Brazil.

Corresponding author: Darcielle Bruna Dias Elias Rua Miguel Gonçalves, 66, apto. 202, Montese - CEP 60420-480 - Fortaleza (CE), Brazil - Tel.: (85) 3292-0416 - e-mail: darcielle.bruna@gmail.com

Received on Jun 28, 2010 - Accepted on Oct 2, 2010.
} 


\section{INTRODUCTION}

The production of reactive oxygen species (ROS) and reactive nitrogen species (RNS) can be observed in human metabolism in several physiological reactions. The body has an efficient antioxidant system that is able to control these reactions. After imbalance between the pro-oxidant and antioxidant systems, oxidative stress can occur, leading to structural and/or functional damages $^{(1)}$.

The human body suffers constant action of free radicals. The main ROS are distributed into two groups: the radical species, including hydroxyl $\left(\mathrm{HO}^{\bullet} \bullet\right.$ ), superoxide $\left(\mathrm{O} 2 \bullet^{-}\right)$, peroxyl $(\mathrm{ROO} \bullet)$ and alcohoxyl $(\mathrm{RO} \bullet)$; and the non-radical species, such as oxygen, hydrogen peroxide and hypochlorous acid. The RNS include nitric oxide $(\mathrm{NO} \bullet)$, nitrous oxide $\left(\mathrm{N}_{2} \mathrm{O}_{3}\right)$, nitrous acid $\left(\mathrm{HNO}_{2}\right)$, nitrites $\left(\mathrm{NO}_{2}^{-}\right)$, nitrates $\left(\mathrm{NO}_{3}^{-}\right)$and peroxinitrites $\left(\mathrm{ONOO}^{-}\right)$. While some of them can be highly harmful to the body, causing damage to the erythrocyte membranes, proteins and DNA, others react only with lipids, causing lipid peroxidation ${ }^{(2-5)}$. Among the classes of molecules that can be damaged by ROS, lipids are most susceptible to oxidation. Degradation of membrane lipids and final products of lipid peroxidation, such as malondialdehyde (MDA) and other aldehydes, is especially harmful, reducing cell viability during sickle cell anemia $(\mathrm{SCA})^{(6)}$.

SCA is a hereditary disease of hemoglobin synthesis determined by hemoglobin S homozygosis (Hb SS), characterized by high morbidity and mortality rates due to increased frequency of vaso-occlusive episodes ${ }^{(7)}$.

$\mathrm{Hb} \mathrm{S}$ is less soluble when deoxygenated and polymerizes in hard fibers, causing microcirculation occlusion. In addition, $\mathrm{Hb} \mathrm{S}$ is less stable, thus causing high concentrations of ROS during SCA. Sickle cells are more fragile than normal erythrocytes and, for this reason, present a shorter lifetime ${ }^{(8)}$.

Patients with SCA are frequently exposed to oxidative stress due to an imbalance between the production of ROS and antioxidant enzymes. The disease is also characterized by damage to the cell membrane due to increased products resulting from lipid peroxidation (MDA and nitrite) and the increased consumption of nitric oxide $(\mathrm{NO})^{(7,9)}$.

The patient with SCA presents vasculopathy due to the production of free radicals and decreased nitric oxide (NO) bioavailability ${ }^{(9)}$. The pathophysiological role of NO has been recently investigated. Due to endothelial dysfunction in patients with sickle cell anemia, endothelin levels are higher than NO levels, thus contributing to vasoconstriction. Literature data suggest that NO may play an important role in the pathophysiology of SCA, particularly during oxidative stress ${ }^{(7,10)}$.
Hydroxyurea (HU) has been used in the treatment of SCA with the purpose of increasing the levels of fetal hemoglobin $(\mathrm{Hb} \mathrm{F})$ and consequently decreasing the vaso-occlusive crises ${ }^{(11)}$. Cokic et al., in 2008, demonstrated significantly elevated levels of GMPc in patients with SCA using hydroxyurea ${ }^{(11)}$. Other studies showed the antioxidant properties of HU by means of inhibition of lipid peroxidation induced by the formation of methemoglobin, justifying its use in the treatment of $\mathrm{SCA}^{(12,13)}$.

\section{OBJECTIVE}

To investigate the serum levels of MDA and nitrite in patients with SCA under treatment or not with HU, followed up at the outpatient's clinic, and to correlate these parameters with the content of MDA and nitrite and the clinical parameters observed in patients with SCA.

\section{METHODS}

\section{Study design}

A cross-sectional, descriptive study carried out in Fortaleza (CE), Brazil, involving adult patients with SCA seen at the outpatient clinic of the Hospital Universitário Walter Cantídio (HUWC), from April 2008 to January 2009. The project was approved by the Institutional Review Board of the Universidade Federal do Ceará (No. 113.12.07).

Sixty-five patients were enrolled and randomized according to inclusion and exclusion criteria. The inclusion criteria were: adults with a diagnosis of SCA confirmed by molecular biology who used or not HU for six months of treatment. The study excluded children with SCA, adults who underwent transfusion in the last three months or receiving iron-chelating agents at the moment of the study, and those who refused to participate in the study. The group was stratified according to the use of HU; Group $1(n=51)$ included patients with SCA who did not use HU and Group $2(\mathrm{n}=14)$ included patients who used HU. Group 3 or control $(n=20)$ included individuals without hemoglobinopathies. Clinical variables were obtained from the medical charts, as well as the data about the use or not of $\mathrm{HU}$ at the usual dose of $20 \mathrm{mg} / \mathrm{kg}$.

\section{Determining malondialdehyde and nitrite levels}

Venous blood samples were drawn from each patient in tubes containing anticoagulant heparin; plasma was isolated to measure MDA and nitrite, and in EDTA to confirm $\mathrm{Hb}$ SS by means of PCR-AE ${ }^{(1)}$ in patients with sickle cell anemia, as well as to confirm of $\mathrm{Hb}$ AA through HPLC in individuals with no hemoglobinopathies. 
The method used to determine MDA was based on its reaction with thiobarbituric acid (TBARS) ${ }^{(15)}$. Nitrite concentration was calculated by the Green method ${ }^{(14)}$.

\section{Statistical analysis}

The data obtained were expressed as mean \pm SEM and analyzed with the statistical program SPSS 15.0. Student's $t$-test was also used to compare the clinical variables with the MDA and nitrite levels. The significance level adopted was $\mathrm{p}<0.05$.

\section{RESULTS}

A predominance of females $(n=33)$ was observed and the mean age of patients with SCA was $31.37 \pm 11.29$ years. The Control Group had lower and more homogeneous MDA levels compared to the other groups. Results from Group $1(\mathrm{p}<0.0001)$ and Group 2 ( $\mathrm{p}<$ $0.0001)$ showed increased MDA levels in relation to the Control Group (Figure 1). When comparing the values of Groups 1 and 2, no significant abnormalities were observed in MDA levels $(\mathrm{p}=0.3154)$ (Figure 1$)$.

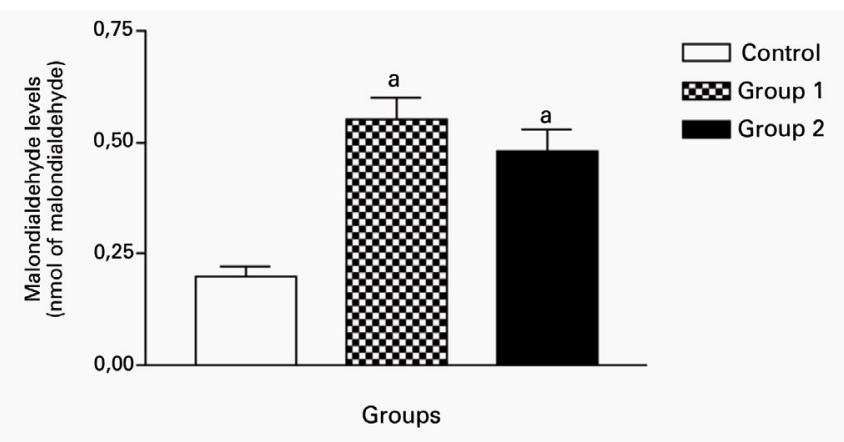

Group 1: Patients with SCA treated with HU; Group 2: Patients with SCA not treated with HU; Control Group: Individuals with no hemoglobinopathies; MDA: malondialdehyde; SCA: sickle cell anemia; HU: hydroxyurea. ${ }^{a} p<0.05$ (ANOVA and Student's $t$ test).

Figure 1. Malondialdehyde (MDA) levels in patients with sickle cell anemia.
When the MDA levels were compared to the clinical variables in patients with SCA, it was observed that in Group 1 there was a correlation with vaso-occlusive crises $(\mathrm{p}<0.0051)$. In turn, in Group 2 the correlation was statistically significant with the clinical variables: two or more transfusions during the year $(\mathrm{p}<0.0469)$, presence of malleolar ulcer $(\mathrm{p}<0.0400)$ and the occurrence of three or more vaso-occlusive crises $(\mathrm{p}<$ 0.0031) (Table 1).

In regard to the serum levels of nitrite, there was a reasonable positive asymmetry for the three groups. There were no significant abnormalities in nitrite contents of Group $1(\mathrm{p}=0.2015)$ and Group $2(\mathrm{p}=0.1305)$ as compared to the Control Group. In turn, there was also no significant abnormality in nitrite levels between groups 1 and 2 ( $p=0.0966)$. Serum levels of nitrite for both groups did not show any significant correlation with the clinical variables.

\section{DISCUSSION}

Data analysis showed that all patients with SCA had increased levels of MDA; however, patients treated with HU presented lower and more homogeneous MDA levels compared to patients with SCA not treated with HU and to the Control Group. These results suggested oxidative damage in all patients regardless of the treatment with HU. In a study carried out in 2008 by Manfredini et al., the presence of increased MDA levels in patients with SCA not treated with HU, when compared to the Control Group was confirmed ${ }^{(16)}$. The results of the current study showed that, in such patients, HU did not inhibit lipid peroxidation. It may be suggested that this discrepancy was probably due to several factors, including the short period of treatment with $\mathrm{HU}^{(3,4)}$.

When evaluating the correlation of MDA levels and the number of vaso-occlusive crises in the last year, a

Table 1. Comparison of clinical variables in relation to malondialdehyde levels (MDA)

\begin{tabular}{|c|c|c|c|c|c|c|c|}
\hline \multirow{3}{*}{ Clinical variables } & & \multicolumn{6}{|c|}{ MDA } \\
\hline & & \multicolumn{2}{|c|}{ Group 1} & \multicolumn{2}{|c|}{ Group 2} & \multicolumn{2}{|c|}{ Group 3} \\
\hline & & Mean \pm SEM & p value & Mean \pm SEM & p value & Mean \pm SEM & p value \\
\hline \multirow{2}{*}{ Sex } & Female & $0.50 \pm 0.14$ & 0.0934 & $0.59 \pm 0.07$ & 0.1233 & $0.54 \pm 0.11$ & 0.1233 \\
\hline & Male & $0.44 \pm 0.11$ & & $0.49 \pm 0.15$ & & $0.45 \pm 0.12$ & \\
\hline \multirow{2}{*}{ Transfusions per year } & 0 to 1 & $0.47 \pm 0.14$ & 0.2711 & $0.54 \pm 0.12$ & $<0.0469^{*}$ & 0 & - \\
\hline & 2 or more & $0.52 \pm 0.10$ & & $0.63 \pm 0.04$ & & 0 & \\
\hline \multirow{2}{*}{ Vaso-occlusive crises } & 1 or 2 & $0.43 \pm 0.12$ & $<0.0051^{*}$ & $0.43 \pm 0.14$ & $<0.0031^{*}$ & 0 & - \\
\hline & 3 or more & $0.53 \pm 0.13$ & & $0.6 \pm 0.05$ & & 0 & \\
\hline \multirow{2}{*}{ Leg/malleolar ulcers } & No & $0.47 \pm 0.12$ & 0.3292 & $0.54 \pm 0.06$ & $<0.0400^{*}$ & 0 & - \\
\hline & Yes & $0.51 \pm 0.15$ & & $0.64 \pm 0.12$ & & 0 & \\
\hline \multirow{2}{*}{ Recurrent infections } & None & $0.46 \pm 0.15$ & 0.3790 & $0.54 \pm 0.11$ & 0.1114 & 0 & - \\
\hline & At least 1 & $0.50 \pm 0.11$ & & $0.64 \pm 0.02$ & & 0 & \\
\hline
\end{tabular}

Group 1: Patients with SCA treated with HU; Group 2: Patients with SCA not treated with HU; Group 3: Individuals with no hemoglobinopathies (control group); MDA: malondialdehyde; SCA: sickle cell anemia; HU: hydroxyurea; SEM: standard error of the mean;

$p<0.05$ (ANOVA and Student's $t$-test).

*Significant. 
statistically significant increase in MDA was observed in two groups of patients with SCA who had three or more vaso-occlusive crises ( $\mathrm{p}<0.005$ for Group 1 and $\mathrm{p}$ $<0.0031$ for Group 2). The same occurred in regard to the MDA levels and the variables of two or more transfusions during the year $(\mathrm{p}<0.0469)$ as well as the presence of malleolar ulcer $(p<0.0400)$ in patients with SCA treated with HU. These results are relevant since they showed that MDA levels are directly proportional to the prognosis modulators in patients with SCA. In 2007, Fasola et al., evaluated the relation between frequency of vaso-occlusive crises and total antioxidant status (TAS) and observed that mean TAS in 25 patients with SCA was lower in those who had three or more vaso-occlusive crises in the previous year ${ }^{(17)}$.

Recent studies suggested that patients with SCA suffer a decrease in NO during the vaso-occlusive crises and in the acute sequestration syndrome ${ }^{(3,4)}$; The levels of NO are inversely proportional to the symptom of pain, so that the decreased bioavailability of NO may contribute to the pathophysiology of SCA ${ }^{(18)}$.

The estimates of the NO levels in this study were carried out by serum measurement of nitrite, a product of NO degradation that presents good sensitivity and stability. Evaluation of the serum levels of nitrite in the three groups studied did not show statistically significant difference among the three groups, probably due to the fact of asymptomatic patients. It was observed that the use of HU may not modify the serum content of nitrite, probably due to the short period of treatment. This finding differs from some studies showing a transient increase of NO during the vaso-occlusive crises in patients with SCA who were treated with $\mathrm{HU}^{(2,19,20)}$. Morris et al. showed increased levels of NO in patients with asymptomatic SCA being treated with $\mathrm{HU}$, and this increase was enhanced by the association of arginine during the treatment ${ }^{(21)}$. On the other hand, Lopez et al., in 2003, observed low levels of L-arginine and NO in adult patients with SCA during vaso-occlusive crises compared to asymptomatic patients with $\mathrm{SCA}^{(22)}$.

It is known that there are three possible mechanis$\mathrm{ms}$ to reduce NO availability in patients with sickle cell anemia: first, due to the low plasma levels of L-arginine; second, through the increased consumption of NO by the ROS; and third, through the consumption of NO by the hemoglobin released in plasma during hemolysis. Recent studies indicated that $50 \%$ of patients with sickle cell anemia present endothelial dysfunction primarily due to the consumption of NO by free hemoglobin in plasma ${ }^{(18)}$.

According to the current results, a real importance in carrying out studies with patients with SCA is showed, since nowadays it is considered a chronic inflammatory disease having peculiarities in regard to abnormalities of oxidative stress. Moreover, the relevance of the presented findings is emphasized for not corroborating the literature; however, few works have covered the topic of this present study. Thus, we expect to contribute to better understanding of the involvement of lipid peroxidation process and serum levels of nitrite in adult patients with sickle cell anemia. These data may provide subsidy for other studies to check the chronic effects of treatment with HU during the pathogenesis of the oxidative stress observed in sickle cell anemia, thus contributing to decrease the impacts of this serious public health problem.

We were not able to confirm the inhibitory effect of $\mathrm{HU}$ in oxidative stress since two groups of patients were compared - one asymptomatic and another with unfavorable disease progression with indication for using HU, with the latter presenting more critical disease manifestations, confirmed by higher MDA levels. Sequential studies evaluating only patients under chronic treatment with HU and at different time points must be carried out to clarify the mechanism of action of $\mathrm{HU}$ in sickle cell anemia.

\section{CONCLUSION}

The results showed that during pathogenesis of SCA it is possible to observe an increase in lipid peroxidation. On the other hand, during treatment with $\mathrm{HU}$ we did not detect any abnormality in the oxidative parameters, probably due to the short period of treatment of the patients studied.

\section{REFERENCES}

1. Vasconcelos SML, Goulart MOF, Moura JBF, Benfato MS, Manfredini V, Kubota LT. Espécies reativas de oxigênio e de nitrogênio, antioxidantes e marcadores de dano oxidativo em sangue humano: Principais métodos analíticos para sua determinação. Quim Nova. 2007;30(5):1323-38.

2. Barreiros ALBS, David JM. Estresse oxidativo: relação entre geração de espécies reativas e defesas do organismo. Quim Nova. 2006;29(1):113-23.

3. Amer J, Filbach E. Chronic oxidative stress reduces the respiratory burst response of neutrophilis from beta-thalassaemia patients. $\mathrm{Br} \mathrm{J}$ Haematol. 2005;129(3):435-41.

4. Klings ES, Farber HW. Role of free radicals in the pathogenesis of acute chest syndrome in sickle cell disease. Resp Res. 2001;2(5):280-5.

5. Chan A, Chow C, Chiu D. Interaction of antioxidants and their implication in genetic anemia. Proc Soc Exp Biol Med. 1999;222(3):274-82.

6. Tukamoto Jr NC. Influência do polimorfismo de GST e peroxidação lipídica no fenótipo de Hb S e mutantes no gene HFE. [dissertação]. São José do Rio Preto (SP): Universidade Estadual Paulista; 2008.

7. Wood KC, Grander DN. Sickle cell disease: Role of reactive oxygen and nitrogen metabolites. Clin Exp Pharmacol. 2007;34(9):926-32. 
8. Wood KC, Hsu LL, Gladwin MT. Sickle cell disease vasculopathy: A state of nitric oxide resistance. Free Rad Biol Méd. 2008;44(8):1506-28.

9. Dhananjay K, Kaul XDL, Xiaoquin Z, Li M, Carleton JCH, Nagel RL. Inhibition of sickle red cell adhesion and vasooclusion in the microcirculation by antioxidants. Am J Physiol Heart Cir Physiol. 2006;291:167-75.

10. Kato GJ, Gladwin MT, Steinberg MH. Deconstructing sickle cell disease: reappraisal of the role of hemolysis in the development of clinical subphenotypes. Blood. 2007;21(1):37-47.

11. Cokic VP, Andric SA, Stojikovic SS, Noguchi CT, Schechter AN. Hydroxyurea nitrosylates and activates soluble guanylyl cyclase in human erythroid cells. Blood. 2008;111(3):1117-23.

12. Cannalli AA. Increased adhesive properties of the neutrophils in sickle cell disease may be reversed by pharmacological nitric oxide donation. Hematol J. 2008;93(4):605-9.

13. Agil A, Sadrzadeh SMH. Hydroxy-urea protects erythrocytes against oxidative damage. Redox Report. 2000;5(1):29-34.

14. Green LC, Tannenbaum sr, Goldman P., Nitrate synthesis in the germfree and conventional rat. Science 1981;212(4490)56-8.

15. Draper HH, Hadley M. Malondial dehyde determination as index of lipid peroxidation. Methods Enzymol.1990;186:421-31.
16. Manfredini V, Lazzaretti LL, Griebeler IH, Santin AP, Brandão VDM, Wagner S, et al. Blood antioxidant parameters sickle cell anemia patients steady state. $\mathrm{J}$ Nat Med Assoc. 2008;100(8):897-902.

17. Fasola F, Adepapo K, Anetor J, Kuti M. Total antioxidants status and some hematological values in sickle cell disease patients in steady state. J Natl Med Assoc. 2007:99(8):891-4.

18. Mack AK, Kato GJ. Sickle cell disease and nitric oxide: A paradigm shift? Int J Biochem. Cell Biol. 2006;38(8):1237-43.

19. Gladwin MT, Shelhamer JH, Ognibene FP, Pease-Fye ME, Nichols JS, Link B, et al. Nitric oxide donor properties of hydroxyurea in patients with sickle cell disease. Br J Haematol. 2002;116(2):436-44.

20. King SB. Nitric oxide production from hydroxiurea. Free Rad Biol Med. 2004;37(6):737-44.

21. Morris CR, Vichinsky EP, Van Warmendam J, Machado L, Kepka-Lenhart $D$, Morris SM Jr, et al. Hydroxyurea and arginine therapy: impact $n$ nitric oxide production in sickle cell disease. J Pediatric Hematol Oncol. 2003;25(8):629-34

22. Lopez BL, Kreshak AA, Morris CR, Davis-Moo L, Ballas SK, Ma XL. L-arginine levels are diminished in adult acute vaso-occlusive sickle cell crisis in the emergency department. Br J Haematol. 2003;120(3):532-4. 